\begin{abstract}
Initiation of insulin therapy is challenging in the primary care setting without nursing support. Doctors have to prepare their practices to deal with these challenges in order not to delay insulin therapy when needed.
\end{abstract}

Keywords: Insulin therapy, challenges, strategies

SFP202 I; 47(1) : 1 2-16

\section{INSULIN THERAPY IN TYPE 2 DIABETES MELLITUS}

Insulin therapy is initiated for patients early in their course of diabetes to relieve symptoms of severe hyperglycaemia or in the hope of achieving remission and during the course of diabetes to attain optimal control. ${ }^{1,2}$ In the specialist outpatient setting, successful initiation of insulin therapy is very much dependent on having dedicated diabetes nurse educators (DNE) who would ensure the smooth transition of the therapy for the patient and the doctor. With the increasing prevalence of diabetes in Singapore, most patients with Type 2 Diabetes Mellitus (T2D) are now receiving their care in the community. The initiation of insulin in the polyclinics is facilitated by nurses trained in diabetes management who can assist with the initiation, optimisation and intensification of the therapy. For family practices that are not often supported by DNE, initiation of insulin therapy may be challenging. This article hopes to share some clinical pointers to help these doctors prepare their practices for their patients who require insulin therapy.

\section{Empowering Patients During Insulin Initiation}

A useful resource that can be obtained easily online is the Royal College of Nursing booklet on "Starting injectable treatment in adults with Type 2 diabetes". ${ }^{3}$ The chapter on a step-by-step guide to insulin therapy includes details on first appointment/ first injection, choosing a delivery device, teaching injection

\author{
DR TAN SENG KIONG \\ Associate Consultant \\ Khoo Teck Puat Hospital \\ DR TAN HWEE HUAN \\ Senior Consultant \\ Khoo Teck Puat Hospital

\section{A/PROF SUM CHEE FANG \\ Senior Consultant \\ Khoo Teck Puat Hospital}

technique, choosing injection site, rotating injection sites, the timing of injection, insulin dosage, storage, and checklist. The following chapter on essential education elaborates on the subjects to be covered at three stages of insulin therapy: immediately upon starting the therapy; within the first few weeks of starting therapy and once the patient is feeling more confident with the therapy. This is a very easy book to read and provides a simple, comprehensive and practical overview for the initiation of insulin therapy.

In preparation for the conversation on insulin therapy with the patient, it is recommended that the practice gathers together the armamentarium or tool kit required for the education and support of insulin therapy. This could include:

1. Blood glucose monitoring (BGM) gadgets glucometer, strips, lancets (include safety lancets that do not require a separate lancing device), lancing device, record book, swabs, and sharps disposal. If available, Flash (intermittent) continuous glucose monitoring demonstration kit or online video. ${ }^{4,5}$

2. Insulin therapy gadgets: vial, disposable prefilled pens, self-fill pens, syringes $(30,50,100 \mathrm{cc} ; 6$ and $8 \mathrm{~mm})$, pen needles (gauge $31-33$, length 4,5 and $6 \mathrm{~mm}$ ), insulin wallets, sharps disposal, and swabs. ${ }^{3,6}$

3. Written information on instructions for insulin dose and time, delivery device, rotating sites, hypoglycaemia management and sick day management.

4. Travel advice and letter for airport securities.

The doctor should be prepared to spend time to proactively engage and work with the patient to deal with the challenges faced with insulin therapy. ${ }^{7,8}$ These anticipated barriers and challenges could be explored with the patient early on and during the course of diabetes to ensure timely initiation of insulin therapy when required. The doctor should be careful not to use insulin therapy as a threat for poor control but rather as an effective therapeutic option. The mnemonic PICK DMP is a useful reminder of the common barriers and challenges encountered. The table below elaborates on the use of this mnemonic. 
Table I: Common barriers in insulin initiation and proposed strategies

\begin{tabular}{|c|c|c|c|}
\hline \multicolumn{2}{|c|}{ Challenges/Barriers } & \multirow[b]{2}{*}{\begin{tabular}{l}
\multicolumn{1}{c}{ Assess } \\
If the fear is \\
perceived or real; \\
show range of \\
needles currently \\
available (smallest: \\
$31-33 \mathrm{G} \times 4-5$ \\
$\mathrm{~mm})$ as compared \\
to those used for \\
drawing of blood \\
$(16-21 \mathrm{G} \times 12-$ \\
$40 \mathrm{~mm})$.
\end{tabular}} & \multirow[b]{2}{*}{\begin{tabular}{l}
\multicolumn{1}{c}{ Strategies } \\
Demonstrate \\
how insulin is \\
administered. Share \\
experiences of \\
others/self. Offer \\
trial injection. Offer \\
insulin port or pump \\
for those on multiple \\
dose injections.
\end{tabular}} \\
\hline Pain & $\begin{array}{l}\text { It is go- } \\
\text { ing to be } \\
\text { painful. }\end{array}$ & & \\
\hline $\begin{array}{l}\text { Inconve- } \\
\text { nience }\end{array}$ & $\begin{array}{l}\text { It will } \\
\text { disrupt } \\
\text { my life- } \\
\text { style. }\end{array}$ & $\begin{array}{l}\text { Current and desired } \\
\text { lifestyle - daily } \\
\text { activities at home, } \\
\text { work (shift work) } \\
\text { or school; meal } \\
\text { times - regularity; } \\
\text { driving; leisure, } \\
\text { physical activity, } \\
\text { travel, fasting } \\
\text { needs; storage - } \\
\text { fridge at home; } \\
\text { insulin wallets. }\end{array}$ & $\begin{array}{l}\text { Demonstrate the } \\
\text { convenience of insulin } \\
\text { pens. Offer to initiate } \\
\text { regimen that will lead } \\
\text { to least disruption. }\end{array}$ \\
\hline Cost & $\begin{array}{l}\text { It is going } \\
\text { to be ex- } \\
\text { pensive. }\end{array}$ & $\begin{array}{l}\text { Cost of current oral } \\
\text { therapy, financial } \\
\text { status, eligibility } \\
\text { for funding. } \\
\text { Understanding } \\
\text { of cost of } \\
\text { complications }\end{array}$ & $\begin{array}{l}\text { Offer cost saving } \\
\text { measures or funding } \\
\text { application. }\end{array}$ \\
\hline
\end{tabular}

\section{CHRONIC DISEASE MANAGEMENT}

\begin{tabular}{|l|l|l|l|}
\hline \multicolumn{2}{|c|}{ Challenges/Barriers } & \multicolumn{1}{c|}{ Assess } & \multicolumn{1}{c|}{ Strategies } \\
\hline $\begin{array}{l}\text { K(C)om- } \\
\text { petence }\end{array}$ & $\begin{array}{l}\text { I'm not } \\
\text { sure I can } \\
\text { handle so } \\
\text { much. }\end{array}$ & $\begin{array}{l}\text { Learning abilities } \\
\text { (cognitive } \\
\text { function), self- } \\
\text { care skills (self- } \\
\text { monitoring of } \\
\text { blood glucose and } \\
\text { interpretation of } \\
\text { results), literacy, } \\
\text { diabetes numeracy, } \\
\text { dexterity, vision, } \\
\text { support }\end{array}$ & $\begin{array}{l}\text { Offer support for } \\
\text { first jab and ongoing } \\
\text { support until } \\
\text { confident. Offer } \\
\text { support from diabetes } \\
\text { centre/specialist clinic } \\
\text { if more assistance/ } \\
\text { training required. } \\
\text { Goal setting to be } \\
\text { decided with patient } \\
\text { using SMART } \\
\text { (specific, measurable, } \\
\text { achievable, relevant/ } \\
\text { realistic and time- } \\
\text { based) and review and } \\
\text { adjusted accordingly. }\end{array}$ \\
& & \\
& &
\end{tabular}

\begin{tabular}{|c|c|c|c|}
\hline Denial & $\begin{array}{l}\text { I'll try } \\
\text { harder; } \\
\text { I don't } \\
\text { need this } \\
\text { yet. } \\
\text { I feel fine. }\end{array}$ & $\begin{array}{l}\text { Understanding of } \\
\text { diabetes as a "silent } \\
\text { killer", concept of } \\
\text { HbA1c as predictor } \\
\text { of complication, } \\
\text { progression of } \\
\text { diabetes and failure } \\
\text { of oral agents (not } \\
\text { patient's failure). }\end{array}$ & $\begin{array}{l}\text { Offer individual or } \\
\text { group education, } \\
\text { peer support. } \\
\text { Stage approach to } \\
\text { initiation of insulin } \\
\text { - raise awareness } \\
\text { andunderstanding of } \\
\text { glycaemic levels and } \\
\text { desired targets through } \\
\text { SMBG training and } \\
\text { interpretation. Offer } \\
\text { trial of insulin with } \\
\text { review date. }\end{array}$ \\
\hline Myth & $\begin{array}{l}\text { If I go on } \\
\text { insulin, } \\
\text { I'll lose a } \\
\text { foot, my } \\
\text { kidney or } \\
\text { end up } \\
\text { dying. } \\
\text { If I start, } \\
\text { I will } \\
\text { need to } \\
\text { continue } \\
\text { for life. }\end{array}$ & $\begin{array}{l}\text { Source of } \\
\text { information; } \\
\text { level of fears and } \\
\text { misunderstanding. } \\
\text { Understanding of } \\
\text { hyperglycaemia } \\
\text { as cause of } \\
\text { complications and } \\
\text { need to achieve } \\
\text { glycaemic targets. } \\
\text { Understanding } \\
\text { of sick-day } \\
\text { management } \\
\text { and risk of } \\
\text { hypoglycaemia. } \\
\text { Understanding } \\
\text { of need for } \\
\text { insulin in Type } 2 \\
\text { Diabetes - insulin } \\
\text { deficiency and } \\
\text { insulin resistance. } \\
\text { Understanding of } \\
\text { benefits of early } \\
\text { initiation of insulin. }\end{array}$ & $\begin{array}{l}\text { Offer evidence from } \\
\text { trials with regards to } \\
\text { safety and efficacy of } \\
\text { insulin therapy; other } \\
\text { patient's testimonies; } \\
\text { peer support group. } \\
\text { Reinforce sick day } \\
\text { management and } \\
\text { hypoglycaemia } \\
\text { management. }\end{array}$ \\
\hline Phobia & \begin{tabular}{|l} 
I can't \\
possibly \\
give \\
myself an \\
injection. \\
I'll have \\
low sugar \\
reactions. \\
I'll get \\
fat.
\end{tabular} & $\begin{array}{l}\text { If there's } \\
\text { needle phobia. } \\
\text { Understanding of } \\
\text { action of insulin, } \\
\text { why hypoglycaemia } \\
\text { happens, how to } \\
\text { avoid and manage } \\
\text { if it happens. } \\
\text { Ability to manage } \\
\text { hypoglycaemia. } \\
\text { Indication for } \\
\text { insulin, fear of } \\
\text { weight gain and } \\
\text { understanding of } \\
\text { reason for weight } \\
\text { gain and measures } \\
\text { to avoid excessive } \\
\text { weight gain. }\end{array}$ & $\begin{array}{l}\text { Offer to refer to } \\
\text { a psychologist. } \\
\text { Caregiver to perform } \\
\text { jabs. Offer auto- } \\
\text { injector, insulin } \\
\text { port. Offer measures } \\
\text { to reduce risk of } \\
\text { hypoglycaemia - start } \\
\text { with low dose and } \\
\text { close monitoring of } \\
\text { response and review } \\
\text { during optimisation } \\
\text { of therapy. Offer } \\
\text { measures to reduce } \\
\text { weight gain - lifestyle } \\
\text { advice, concomitant } \\
\text { use with SGLT-2 } \\
\text { inhibitors, GLP-RA } \\
\text { and metformin. }\end{array}$ \\
\hline
\end{tabular}




\section{Steps to Insulin Initiation and Intensification of Therapy}

The doctor should consider initiating insulin therapy when:

1. Glycaemic targets are not met on optimal treatment with oral glucose-lowering agents.

2. Patient has symptomatic hyperglycaemia.

There are various formulations of insulins that the doctor may choose. The Appropriate Care Guide (ACE) on Initiating Basal Insulin in Type 2 Diabetes Mellitus ${ }^{10}$ is a useful resource to guide doctors in their choice of basal insulin and steps in titration. Basal insulin can be started at a dose of $0.1-0.2$ units $/ \mathrm{kg} /$ day depending on the patient's age, comorbidities and blood glucose profile. The dose can be titrated by 2-4 units once or twice a week until the target fasting blood glucose is achieved. Should the patient's HbA1c remain poorly controlled, and the patient has postprandial hyperglycaemia or a basal insulin dose that exceeds 0.5 units $/ \mathrm{kg} /$ day, the doctor should consider adding on prandial insulin. This can be done in form of basal-plus, basal-bolus or premixed (biphasic) insulin, depending on the patient profile. Injectable GLP-1 receptor agonists may also be considered.

\section{Diagram I: Algorithm for insulin therapy}

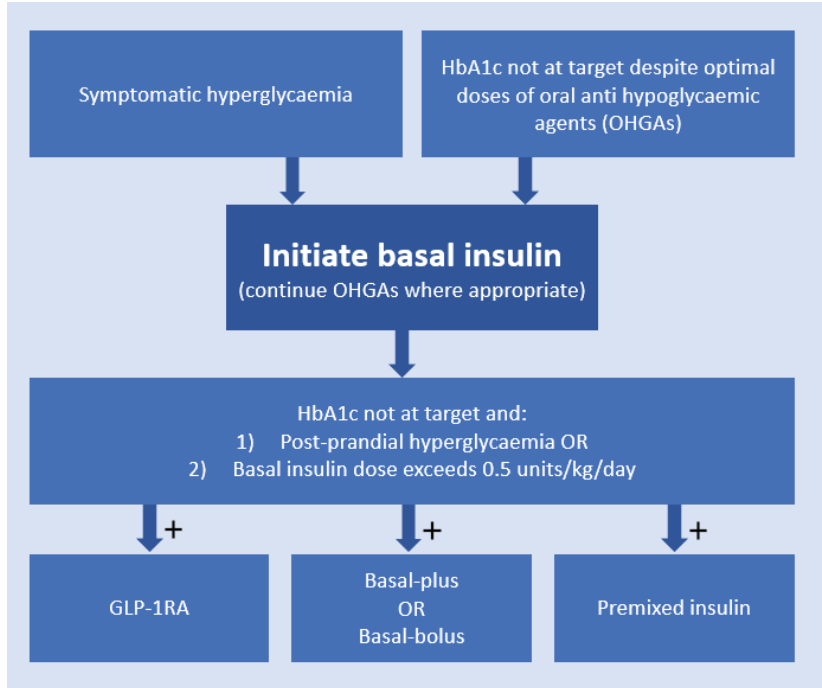

Insulin prescription is made easier if the doctor can figure out the glycaemic profile of the patient. ${ }^{1,9}$ A prescription of BGM to be performed by the doctor, patient or caregiver should first be given to evaluate the glycaemic profile of the patient. It can be done using the FITT model as illustrated below:
Table 2: FITT model for BGM

\begin{tabular}{|c|c|c|c|}
\hline Frequency & Intensity & Time & $\begin{array}{l}\text { Targets - to be } \\
\text { individualised }\end{array}$ \\
\hline $\begin{array}{l}\text { Daily for } \\
\text { three days }\end{array}$ & 2 points & BT \& FBG & $\begin{array}{l}\text { FBG: } 4-7 \mathrm{mmol} / \mathrm{L} ; \\
\text { BT } 7-10 \mathrm{mmol} / \mathrm{L}\end{array}$ \\
\hline $\begin{array}{l}\text { Once a } \\
\text { week }\end{array}$ & 2 points & FBG \& PD & $\begin{array}{l}\text { FBG: } 5-8 \mathrm{mmol} / \mathrm{L} \text {; } \\
\text { PD: } 5-8 \mathrm{mmol} / \mathrm{L}\end{array}$ \\
\hline $\begin{array}{l}\text { On off days } \\
\text { or weekend }\end{array}$ & $\begin{array}{l}2 \text { up to } 7 \\
\text { points }\end{array}$ & $\begin{array}{l}\text { Before and } \\
2 \text { hours } \\
\text { after } \\
\text { meals \& } \\
\text { BT }\end{array}$ & $\begin{array}{l}\text { Pre-meal } \mathrm{BG}<7 \mathrm{mmol} / \mathrm{L} ; \\
\text { post-meal BG }<10 \mathrm{mmol} / \mathrm{L}\end{array}$ \\
\hline
\end{tabular}

Legend: FBG: fasting blood glucose; PD: pre-dinner; BT: bedtime

\section{Figure I: Examples of glycaemic profiles and proposed clinical management}

Glucose

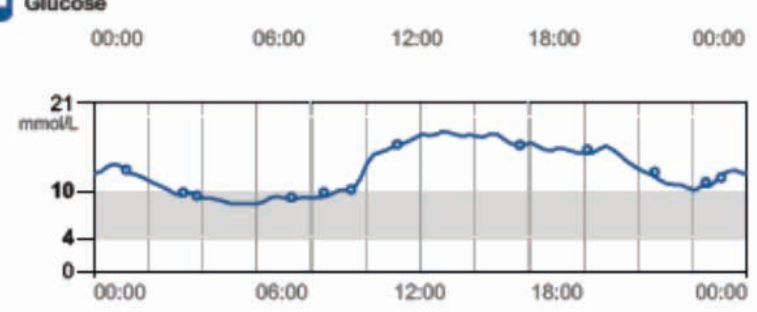

All day hyperglycaemia

BGM: BT \& FBG

Insulin: Basal insulin - once a day either morning or bedtime

Glucose

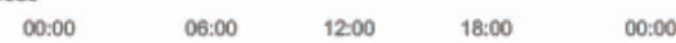

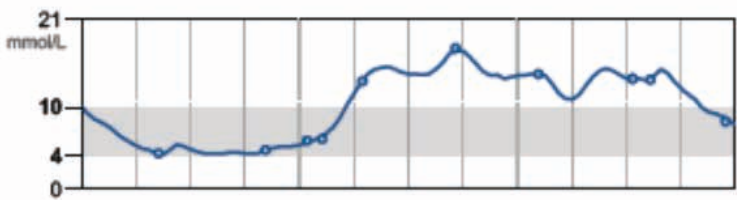

Daytime hyperglycaemia

BGM: FBG, Pre-lunch and Pre-dinner

Insulin: Premixed (30/70) at breakfast

Glucose

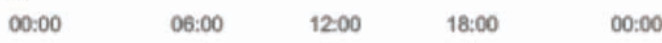

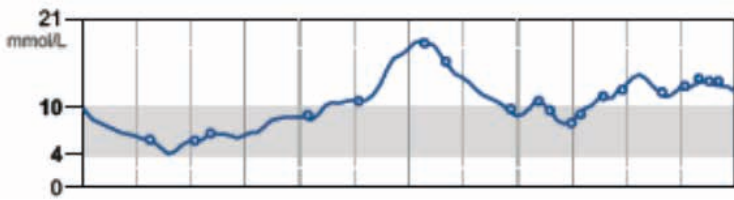

Predominant postprandial hyperglycaemia.

BGM: Pre-meal \& mid-day

Insulin: Premixed (50/50) at culprit meal 
Glucose

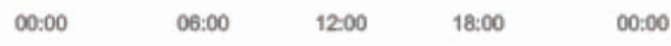

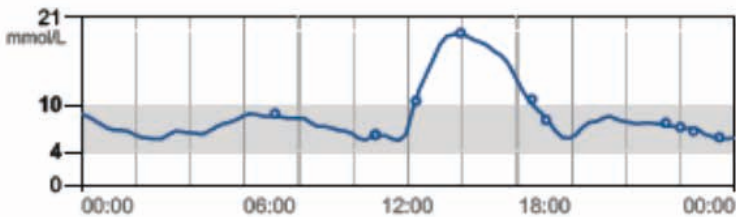

Predominant postprandial hyperglycaemia.

BGM: Pre and post-meal

Insulin: Prandial insulin

Desired blood glucose levels after initiation of insulin therapy:
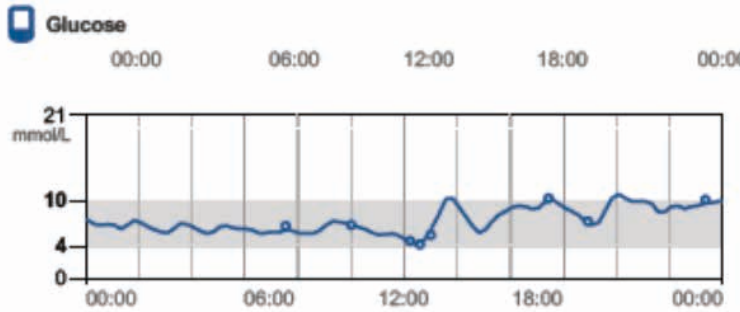

Normoglycaemia.

BGM: FBG; when hungry

No evidence of hypoglycaemia.

Legend: FBG: fasting blood glucose; BT: bedtime

\section{BEWARE OF HYPOGLYCAEMIC UNAWARENESS}

Hypoglycaemic unawareness occurs when the patient does not develop the early warning symptoms of hypoglycaemia when their blood glucose levels are low. These symptoms include tremors, palpitations and diaphoresis. This may occur when the patients have repeated episodes of hypoglycaemia or concomitant autonomic neuropathy, and this results in a significant increase risk of developing severe hypoglycaemia. Patients with hypoglycaemic unawareness should be advised to increase their glycaemic targets for a few weeks to avoid hypoglycaemia.

\section{CONCLUSION}

In summary, insulin therapy is an important and effective therapeutic option in the management of Type 2 diabetes. Initiation, optimisation and intensification will be challenging if doctors are not prepared to deal with the challenges. With careful preparation as proposed above, insulin therapy can be initiated safely and effectively even in primary care setting.

\section{REFERENCES:}

I. American Diabetes Association. 9. Pharmacologic Approaches to Glycemic Treatment: Standards of Medical Care in Diabetes-2020. Diabetes Care. 2020 Jan;43(Suppl I):S98.

2. Kramer CK, Zinman B, Retnakaran R. Short-term intensive insulin therapy in type 2 diabetes mellitus: a systematic review and metaanalysis. The lancet Diabetes \& endocrinology. 2013 Sep I; I I):2834.

3. Royal College of Nursing. Starting injectable treatment in adults with Type 2 diabetes. RCN guidance or nurses [pdf]. 2012 [accessed I Dec. 2020] Available from: https://www.penninegP-training.co.uk/res/Starting\%20Insulin\%20in\%20Type\%202\%2 DM.pdf

4. Beck RW, Riddlesworth TD, Ruedy K,Ahmann A, Haller S, Kruger D, McGill JB, Polonsky W, Price D, Aronoff S, Aronson R. Continuous glucose monitoring versus usual care in patients with type 2 diabetes receiving multiple daily insulin injections: a randomised trial.Annals of internal medicine. 2017 Sep 19;167(6):365-74.

5. Carlson AL, Mullen DM, Bergenstal RM. Clinical use of continuous glucose monitoring in adults with type 2 diabetes. Diabetes technology \& therapeutics. 2017 May I;19(S2):S-4.

6. Frid AH, Kreugel G, Grassi G, Halimi S, Hicks D, Hirsch LJ, Smith MJ, Wellhoener R, Bode BW, Hirsch IB, Kalra S. New insulin delivery recommendations. InMayo Clinic Proceedings 2016 Sep I (Vol. 91, No. 9, pp. I23।-I255). Elsevier.

7. Karter AJ, Subramanian U, Saha C, Crosson JC, Parker MM, Swain $\mathrm{BE}$, Moffet $\mathrm{HH}$, Marrero DG. Barriers to insulin initiation: the translating research into action for diabetes insulin starts project. Diabetes Care. 2010 Apr;33(4):733-5.

8. Polonsky WH, Henry RR. Poor medication adherence in type 2 diabetes: recognising the scope of the problem and its key contributors. Patient preference and adherence. 2016; 10:1299.

9. Kalra S, Czupryniak L, Kilov G, Lamptey R, Kumar A, Unnikrishnan AG, Boudiba A, Abid M, Akanov ZA, Latheef A, Araz M. Expert Opinion: Patient Selection for Premixed Insulin Formulations in Diabetes Care. Diabetes Therapy. 2018 Dec I: I-5.

10. Agency for Care Effectiveness. Appropriate Care Guide (ACE): Initiating basal insulin in type 2 diabetes mellitus 2017 [Internet] Singapore: ACE [updated 20 November 2017, cited I December 2020]. Available from: https://www.ace-hta.gov.sg/public-data/ our-guidance/Initiating\%20basal\%20insulin\%20in\%20T2DM\%20 (For\%20ACE\%20website\%2020\%20Nov\%202017).pdf

\section{RECOMMENDED READINGS:}

I. American Diabetes Association. 9. Pharmacologic Approaches to Glycemic Treatment: Standards of Medical Care in Diabetes-2020. Diabetes Care. 2020 Jan;43(Suppl I):S98.

2. Royal College of Nursing. Starting injectable treatment in adults with Type 2 diabetes. RCN guidance or nurses [pdf]. 2012 [assessed I Dec. 2020] Available from: https://www.pennine-gptraining.co.uk/res/Starting\%20Insulin\%20in\%20Type\%202\%20DM. pdf

3. Frid AH, Kreugel G, Grassi G, Halimi S, Hicks D, Hirsch LJ, Smith MJ, Wellhoener R, Bode BW, Hirsch IB, Kalra S. New insulin delivery recommendations. InMayo Clinic Proceedings 2016 Sep I (Vol. 9I, No. 9, pp. I23 I-I255). Elsevier.

4. Agency for Care Effectiveness. Appropriate Care Guide (ACE): Initiating basal insulin in type 2 diabetes mellitus 2017 [Internet]. Singapore: ACE [updated 20 November 2017, cited I December 2020]. Available from: https://www.ace-hta.gov.sg/public-data/ our-guidance/Initiating\%20basal\%20insulin\%20in\%20T2DM\%20 (For\%20ACE\%20website\%2020\%20Nov\%202017).pdf 


\section{LEARNING POINTS}

- Insulin therapy should be introduced as an effective therapeutic option and not used as a threat for poor control.

- Challenges faced with insulin therapy should be managed with patients early in their course of diabetes.

- Clinicians have to be prepared to deal with the challenges faced with insulin therapy. 